\title{
PENERAPAN METODE HARGA POKOK PROSES DALAM PENENTUAN HARGA JUAL PRODUKSI KASUR PADA USAHA KASUR MEMBALI JAYA DI KOTA BAUBAU
}

\author{
Dwi Agustyawati \\ Program Studi Akuntansi, Fakultas Ekonomi \\ Universitas Muhammadiyah Buton, Baubau, Indonesia \\ e-mail :partyazh@gmail.com
}

\begin{abstract}
ABSTRAK
Penelitian ini bertujuan untuk mengetahui bagaimana penerapan metode harga pokok proses dalam penentuan harga jual produksi kasur pada Usaha Kasur Membali Jaya. Metode analisis yang dipakai adalah analisis deskriptif kuantitatif.

Hasil penelitian menunjukan bahwa biaya-biaya produksi yang dikeluarkan oleh Usaha Kasur Membali Jaya pada Tahun 2016 adalah sebesar Rp889.350.000 dimana jumlah biaya bahan baku yang dibebankan adalah sebesar Rp 650.400.000, jumlah biaya bahan penolong sebesar Rp38.125.000, jumlah biaya tenaga kerja sebesar Rp162.000.000, jumlah biaya overhead pabrik sebesar Rp38.825.000. Biaya produksi kasur per satuan adalah sebesar Rp229.711. Total pendapatan Usaha Kasur Membali Jaya pada Tahun 2016 sebesar Rp140.400.000.
\end{abstract}

Kata Kunci:Biaya Produksi, Metode Proses, Full Costing

\begin{abstract}
This study aims to find out how the application of the cost of process method in determining the selling price of mattress production at the Membali Jaya Mattress Business. The analytical method used is quantitative descriptive analysis.

The results showed that the production costs incurred by the Returning Mattress Business in 2016 amounted to Rp889,350,000 where the total cost of raw materials charged was Rp 650,400,000, the total cost of supporting materials was Rp38,125,000, total labor costs amounting to $R p$ $162,000,000$, the total factory overhead costs amounting to $R p$ 38,825,000. The cost of producing a mattress per unit is Rp229,711, the total revenue from the Returning Mattress Business in 2016 amounted to Rp140,400,000.
\end{abstract}

Keywords: Production Cost, Process Method, Full Costing

\section{PENDAHULUAN}

Seiring dengan semakin pesatnya perkembangan teknologi industri dewasa ini menuntut banyak perusahaan untuk bersaing dan mempertahankan kelangsungan hidupnya.Perusahaan tersebut harus dikelola dengan efektif dan efisien sehingga tujuan perusahaan dapat tercapai dengan baik.

Tujuan utama suatu perusahaan adalah dapat mencapai laba yang maksimal.Untuk mencapai laba yang maksimal tersebut tentunya perusahaan membutuhkan informasi 
tentang biaya yang akurat yang dapat membantu pihak manajemen dalam pengambilan keputusan.

Akuntansi sebagai salah satu cabang ilmu ekonomi didalamnya juga membahas masalah penyajian informasi biaya yang disebut dengan istilah akuntansi biaya [1]. Kebutuhan akan informasi biaya sangatlah diperlukan, hal ini disebabkan perhitungan biaya sangat berpengaruh pada penentuan harga pokok produksi [2]. Sebagaimana diketahui bahwa unsur-unsur harga pokok produksi adalah biaya bahan baku, biaya tenaga kerja langsung, dan biaya overhead pabrik, sehingga diperlukan kecermatan dan kejelian dalam menyajikan informasi ketiga biaya tersebut [3].

Dalam penentuan harga pokok produk dapat menggunakan dua metode, yaitu metode harga pokok proses dan metode harga pokok pesanan. Metode harga pokok proses (procces costing) digunakan oleh perusahaan yang berproduksi massal, dalam hal ini biaya-biaya produksi dikumpulkan untuk periode tertentudan biaya produksi persatuan produk yang dihasilkan dalam periode tersebut dihitung dengan cara membagi total biaya produksi untuk periode tersebut dengan satuan produksi yang dihasilkan dalam periode yang bersangkutan. Metode harga pokok pesanan (job order costing) digunakan oleh perusahaan yang berproduksi berdasarkan pesanan, melakukan pengelolaan produk atas dasar pesanan yang diterima dari pihak luar. Dalam metode ini biaya-biaya produksi dikumpulkan untuk pesanan tertentu dan harga pokok produksi per satuan produk yang dihasilkan untuk memenuhi pesanan tersebut dihitung dengan cara membagi total biaya produksi untuk pesanan tersebut dengan jumlah satuan produk dalam pesanan yang bersangkutan[4].

Dalam pengumpulan biaya produksi dalam suatu perusahaan selalu dipengaruhi oleh karakteristik kegiatan produksi perusahaan tersebut.Apakah perusahaan tersebut melakukan produksi terus-menerus atau terputus-putus sesuai pesanan yang diterima dari pihak luar. Informasi mengenai metode pengumpulan harga pokok produksi ini sangat penting bagi perusahaan terutama pihak manajemen, apabila perusahaan tersebut berproduksi massa. Hal ini dikarenakan harga pokok proses mengumpulkan biaya produksi per departemen produksi per periode akuntansi [5].

Berdasarkan hal yang dikemukakan di atas tampak dengan jelas bahwa diperlukan suatu metode dalam menentukan harga pokok produksi. Dengan metode harga pokok proses seperti halnya Usaha Kasur Membali Jaya di kerjakan secara industri rumahan (home industry). Industri rumahan ini memiliki usaha pembuatan kasur yang berbahan dasar kapuk yang seluruh bidang usahanyadikerjakan secara terus menerus 
untukmemproduksi secara massal. Biaya untuk produk yang dihasilkan berupa kasur rata-rata tanpa menggunakan penerapan metode harga pokok dalam proses yang benar sehingga penentuan harga pokok penjualan (HPP), menghitung laba atau rugi periodik dilakukan secara acak dan secara tidak langsung akan mempengaruhi pendapatan yang ditetapkan perusahaan.

\section{METODE PENELITIAN}

Populasi merupakan suatu wilayah yang terdiri atas objek/subjek yang mempunyai kuantitas dan karakteristik tertentu, yang ditetapkan oleh peneliti untuk di pelajari kemudian ditarik satu kesimpulan [6], populasi dalam penelitian ini adalah laporan produksi Usaha Kasur Membali Jaya Kota BauBau.Sampel adalah bagian dari populasi yang diambil melalui cara-cara tertentu yang juga memiliki karakteristik tertentu, jelas dan lengkap yang dianggap bisa mewakili populasi [7]. Dengan kata lain sampel adalah sebagian atau wakil populasi yang di teliti. Sampel penelitian ini adalah laporan produksi pada Tahun 2016.

Jenis data yang digunakan dalam penelitian nantinya antara lain data kuantitatif dan data kualitatif. Data kuantitatif dalam penelitian ini yaitu berupa laporan produksi perusahaan/ industri pembuatan kasur Membali Jaya Kota Baubau.Data kualitatif yaitu data yang berbentuk kata, kalimat, tabel dan gambar berupa struktur organisasi, sejarah perusahaan dan pembagian tugas, masing-masing komponen pada usaha kasur Membali Jaya Kota Baubau.

Data yang diperoleh dalam penelitian ini bersumber dari data primer dan data sekunder.Data primer yaitu data yang diperoleh langsung dari sumbernya.Diambil dan dicatat pertama kalinya.Data primer dalam penelitian ini adalah data yang berkaitan dengan harga pokok produksi, data tenaga kerja yang diperoleh melalui metode dokumentasi.Data sekunder yaitu data yang diusahakan sendiri pengumpulannya oleh peneliti. Data sekunder dalam penelitian ini adalah berupa literatur-literatur yang berkaitan dengan materi penelitian [8].Adapun yang menjadi metode pengumpulan data [9] adalah:

1. Wawancara, yaitu dengan melakukan tanya jawab secara langsung dengan para karyawan dan pimpinan usaha kasur Membali Jaya Kota Baubau.

2. Kepustakaan (library research), yaitu suatu tehnik pengumpulan data dengan cara mengumpulkan bahan-bahan dari berbagai sumber dan mempelajari literatur- 
literatur yang berhubungan dengan teknik pembahasan untuk memperoleh dasar teoritis.

3. Observasi, mengumpulkan data dengan cara mengamati objek yang di teliti secara langsung.

Adapun metode analisis data yang digunakan dalam penelitian ini adalah menggunakan metode penentuan biaya produksi dengan pendekatan full costing yang akan dapat memberikan gambaran biaya produksi kasur pada usaha kasur Membali Jaya Kota Baubau, dan secara terperinci akan di jelaskan sebagai berikut:

1. Untuk dapat mengetahui biaya produksi kasur, maka akan diketahui dengan menjumlahkan keseluruhan biaya produksi yang dikeluarkan oleh usaha kasur dengan pendekatan full costing. Dengan rumus perhitungan adalah :

Metode Full Costing :

$\begin{array}{ll}\text { Biaya bahan baku } & \mathrm{xxxx} \\ \text { Biaya bahan penolong } & \mathrm{xxxx} \\ \text { Biaya tenaga kerja } & \mathrm{xxxx} \\ \text { Biaya overheadpabrik } & \underline{\mathrm{xxxx}} \\ \text { Total biaya produksi } & \underline{\mathrm{xxxx}}\end{array}$

Sumber: (Mulyadi 2000: 19)

2. Untuk mengetahui perhitungan harga pokok produksi per satuan, maka akan diketahui dangan membagi jumlah biaya produksi kasur dengan hasil produksi yang diperoleh (unit ekuivalensi). Rumus perhitungannya adalah:

Harga pokok produksi per satuan $=$

Jumlah biaya produksi

Unit ekuivalensi

3. Untuk mengetahui laba yang didapat maka, pendapatan usaha kasur dikurangi dengan keseluruhan biaya produksi [10].Rumus yang digunakan:

Keuntungan $=$ Hasil Penjualan Total - Biaya Produksi Total

Sumber: (Sadono Sukirno 2004) 


\section{HASIL DAN PEMBAHASAN}

\section{a. Hasil Penelitian}

\section{Proses Produksi}

Proses produksi dapat diartikan sebagai cara atau segala tindakan yang diarahkan kepada usaha untuk menciptakan atau menambah kegunaan suatu barang dengan memanfaatkan sumber-sumber yanng tersedia. Oleh karena itu masalah-masalah yang berkaitan dengan proses produksi perlu ditanggapi secara cermat oleh para pengelola perusahaan. Karena fungsi produksi merupakan pertanggungjawaban atas pengelolaan bahan baku dan bahan pembantu atau bahan penolong menjadi barang jadi atau jasa yang akan memberikan hasil pendapatan bagi perusahaan.

Jadi dalam melakukan proses produksi perlu ditangani dengan cermat, agar produk yang dihasilkan memiliki mutu dan kualitas yang baik sehingga pada saat dipasarkan atau dijual pada konsumen atau pembeli merasa puas dan dapat memberikan keuntungan bagi perusahaan.

Usaha kasur Membali Jaya mengelolah atau memproduksi bahan dasar kapuk menjadi kasur yang dilakukan secara terus-menerus.Produksi kasur ini masih di lakukan secara home industry atau di lakukan secara industri rumahan.

Berdasarkan hasil pengamatan dan wawancara dengan narasumber pada objek penelitian diperoleh informasi bahwa proses pembuatan kasur kapuk melalui beberapa tahapan dengan penggunaan berbagai macam bahan baku, bahan penolong, serta peralatan yang terdiri dari:

1. Bahan Baku meliputi:
a. Kapuk
b. Kain

2. Bahan penolong meliputi :
a. Plastik pembungkus
b. Tali rapia
c. Benang Lanti
d. Benang jahit

3. Mesin dan peralatan meliputi :
a. Mesin pemisah
b. Meter
c. Gunting
d. Jarum 
e. Pipa 2. $1 / 2$ inci

Adapun urutan proses produksi mulai dari bahan bakuhingga menjadi produk jadi, secara keseluruhan akan dijelaskan sebagai berikut.

1. Bahan baku yang dibutuhkan dalam proses produksi adalah kapuk.

2. Pemisahan yaitu proses pemisahan bahan baku kapuk dengan bijinya dengan cara didaur menggunakan mesin pendaur.

3. Pengisian kapuk ke dalam kain yang telah ditentukan ukurannya dengan menggunakan pipa.

4. Kasur yang sudah jadi kemudian dijahit.

5. Pembungkusan. Dari kasur yang sudah jadi kemudian dilakukan pembungkusan terhadap kasur tersebut.

6. Proses penyimpanan produk siap dijual.Dalam proses ini, barang yang telah di produksi disimpan atau dijual kepada konsumen.

\section{b. Pembahasan}

\section{Pencatatan Harga Pokok Produk}

Pencatatan harga pokok produk yang dikeluarkan oleh usaha kasur Membali Jaya pada Tahun 2016 dapat kita lihat pada tabel di bawah ini:

\section{Tabel 1.Data Produksi dan Biaya} Usaha Kasur Membali Jaya Tahun 2016

\begin{tabular}{|l|c|}
\hline Jenis Biaya & Jumlah \\
\hline Biaya bahan baku & $\mathrm{Rp} 650.400 .000$ \\
Biaya bahan penolong & $\mathrm{Rp} 38.125 .000$ \\
Biaya tenaga kerja & $\mathrm{Rp} 162.000 .000$ \\
Biaya overhead pabrik & $\mathrm{Rp} 38.825 .000$ \\
\hline Total biaya produksi & $\mathrm{Rp} 889.350 .000$ \\
\hline
\end{tabular}

Jumlah produk yang dihasilkan selama Tahun 2016 adalah:

Produk jadi 2.500 buah

Produk dalam proses pada akhir tahun 1.500 buah, dengan tingkat penyelesaian sebagai berikut:

Biaya bahan baku; $100 \%$

Biaya tenaga kerja $70 \%$ biaya overhead pabrik $50 \%$ 


\section{Data produksi Tahun 2016}

Masuk kedalam proses: 4.000 buah

Produk jadi: 2.500 buah

Produk dalam proses akhir : ... 1.500 buah

Untuk menghitung biaya per satuan yang dikeluarkan oleh usaha kasur Membali Jaya perlu dilakukan perhitungan biaya produksi per satuan yang dikeluarkan pada Tahun 2016. Setelah biaya produksi per satuan dihitung maka, harga pokok produk jadi yang ditransfer ke gudang dan harga pokok persediaan produk dalam proses pada usaha kasur Membali Jaya perlu dihitung unit ekuivalen Tahun 2016 dengan cara perhitungan sebagai berikut:

1. Biaya bahan baku yang dikeluarkan Tahun 2016 tersebut dapat menghasilkan 2.500 buah produk jadi dan 1.500 buah persediaan produk dalam proses dengan tingkat penyelesaian biaya bahan baku sebesar $100 \%$. Hal ini berarti bahwa biaya bahan baku sebesar Rp 650.400.000tersebut telah digunakan untuk menyelesaikan produk sebanyak 2.500 buah dan 1.500 buah persediaan produk dalam proses. Dengan demikian unit ekuivalen biaya bahan baku adalah 4.000 buah, yang dihitung sebagai berikut: $2.500+(100 \% \times 1.500)=4.000$

2. Biaya bahan penolong yang di keluarkan di Tahun 2016 sebesar Rp 38.125.000 tersebut dapat menghasilkan 2.500 buah produk jadi dan 1.500 buah persediaan produk dalam proses dengan tingkat penyelesaian biaya bahan persediaan produk dalam proses dengan tingkat penyelesaian biaya bahan penolong sebesar 100\%. Hal ini berarti bahwa biaya bahan penolong tersebut telah digunakan untuk menyelesaikan produk sebanyak 2.500 buah dan 1.500 buah persediaan produk dalam proses. Dengan demikian unit ekuivalen biaya bahan penolong adalah 4.000 buah, yang dihitung sebagai berikut : $2.500+(100 \% \times 1.500)=4.000$

3. Biaya tenaga kerja yang dikeluarkan pada Tahun 2016 sebesar Rp162.000.000 tersebut dapat menghasilkan 2.500 buah produk jadi dan 1.500 buah persediaan produk dalam proses dengan tingkat penyelesaian biaya tenaga kerja sebesar $70 \%$. Hal ini berarti bahwa biaya tenaga kerja tersebut telah digunakan untuk menyelesaikan produk sebanyak 2.500 buah dan 1.050 buah (70\% x 1.500) persediaan produk dalam proses. Dengan demikian unit ekuivalen biaya tenaga kerja adalah 3.550 buah, yang dihitung sebagai berikut: $2.500+(70 \%$ x 1.500 $)=3.550$

4. Biaya overhead pabrik yang dibebankan dalam Tahun 2016 sebesar Rp 38.825 .000 tersebut dapat menghasilkan 2.500 buah produk jadi dan 1.500 buah persediaan 
produk dalam proses dengan tingkat penyelesaian biaya tenaga kerja sebesar $50 \%$.

Hal ini berarti bahwa biaya overheadpabrik tersebut telah di gunakan untuk menyelesaikan produk sebanyak 2.500 buah dan 750 buah $(1.500 \times 50 \%)$ persediaan produk dalam proses. Dengan demikian unit ekuivalen biaya overhead pabrik adalah 3.250 buah, yang di hitung sebagai berikut : $2.500+(50 \% \times 1.500)=3.250$

Hasil perhitungan ini kemudian dikalikan dengan kuantitas produk jadi dan akan dihasilkan informasi harga pokok produk jadi yang ditransfer ke gudang. Perhitungan biaya per satuan dapat kita lihat pada tabel dibawah ini:

\section{Tabel 2.Perhitungan Harga Pokok Produksi Per Satuan}

\begin{tabular}{|l|r|r|r|}
\hline Unsur Biaya Produksi & \multicolumn{1}{c|}{ Total Biaya } & Unit Ekuivalen & \multicolumn{1}{c|}{ Biaya Produksi } \\
\hline \multicolumn{1}{|c|}{$(1)$} & \multicolumn{1}{c|}{$(2)$} & $(3)$ & $(2):(3)$ \\
\hline Bahan baku & Rp 650.400.000 & 4.000 & Rp 162.600 \\
Bahan penolong & 38.125 .000 & 4.000 & 9.531 \\
Tenaga kerja & 162.000 .000 & 3.550 & 45.634 \\
Biaya Overhead pabrik & 38.825 .000 & 3.250 & 11.946 \\
\hline \multicolumn{1}{|c|}{ Total } & Rp 889.350.000 & & Rp 229.711 \\
\hline
\end{tabular}

\section{KESIMPULAN}

Berdasarkan hasil analisa yang telah dikemukakan maka kesimpulan yang dapat ditarik adalahsebagai berikut.Biaya produksi yang dikeluarkan oleh Usaha Kasur Membali Jaya pada Tahun 2016 adalah sebesar Rp889.350.000, dimana jumlah biaya bahan baku yang dibebankan adalah sebesar Rp650.400.000, jumlah biaya bahan penolong sebesar Rp38.125.000, jumlah biaya tenaga kerja sebesar Rp162.000.000, jumlah biaya overhead pabrik sebesar Rp38.825.000.Biaya produksi kasur per satuan adalah sebesar Rp229.711, dimana nilai ekuivalen bahan baku sebesar $\mathrm{Rp} 162.600$, nilai ekuivalensi bahan penolong sebesar Rp9.531 nilai ekuivalensi tenaga kerja Rp45.634 dan nilai ekuivalensi biaya overhead pabrik sebesar Rp11.946.

Total pendapatan usaha kasur Membali Jaya pada Tahun 2016 sebesar Rp146.400.000, dimana total penjualan pada Tahun 2016 adalah sebesar Rp1.040.000.000, dan pengeluaran atau biaya pembelian bahan baku, biaya bahan penolong, biaya tenaga kerja dan biaya overhead pabrik sebesar Rp889.350.000, biaya operasional (biaya administrasi dan umum dan biaya pemasaran) sebesar Rp 4.250.000. 


\section{SARAN}

Adapun saran yang direkomendasikan dari hasil penelitian ini adalah sebagai berikut: (1) diharapkan perlunya perhatian dan bantuan dari pihak investor baik pemerintah maupun pihak swasta dalam membantu mengembangkan Usaha Kasur Membali Jaya; (2) pimpinan Usaha Kasur Membali sebaiknya membuat suatu usaha yang berbadan hukum, misalnya Koperasi, CV atau PT; dan (3) perlunya diadakan kegiatan pelatihan atau sosialisasi oleh pihak-pihak terkait baik dari pemerintah maupun swasta dalam pemberian pengetahuan tentang pentingnya pencatatan biaya - biaya produksi yang dikeluarkan dalam produksi kasur.

\section{DAFTAR PUSTAKA}

[1] Noor, Henry Faizal. 2008.Ekonomi Manajerial. Jakarta: PT Raja Grafindo Persada.

[2] Halim, Abdul.2000. Dasar-Dasar Akuntansi Biaya Edisi Kelima. Yogyakarta: BPFE.

[3] Daljono. 2004.Akuntansi Biaya Penentuan Harga Pokok dan Pengendalian Edisi 2. Semarang: BP Universitas Diponegoro.

[4] Mulyadi. 2005. Akuntansi BiayaEdisi 5. Yogyakarta: STIE YKPN.

[5] Supriyono. R.A. 2003.Akuntansi Biaya Pengumpulan Biaya dan Penentuan Harga Pokok, Jilid Satu, Edisi Keempat. Yogyakarta: BPFE

[6] Sugiyono. 2010. Statistik Untuk Penelitian. Bandung: Alfabeta.

[7] Hasan, Iqbal. 2002. Pokok-Pokok Materi Metodologi Penelitian Kuantitatif Dalam Pendidikan. Jakarta: PT Raja Grafindo.

[8] Nasir, M. 2003. Metode Penelitian. Jakarta: Ghalia Indonesia.

[9] Indriantoro, Nur. 2002. Penelitian Bisnis Untuk Akuntansi dan Manajemen.Edisi 2. Yogyakarta: BPFE.

[10] Sukirno, Sadono. 2004. Pengantar Pengantar Teori Makroekonomi. Jakarta: PT. Raja Grafindo Persada. 